Ivan Nikolić1

Sanja Filipović ${ }^{2}$
JEL: Q41, Q52

DOI:10.5937/industrija\%v-25514

UDC:338.516:621.31(497.11:4-672EU)

621.316

Original Scientific Paper

\title{
How energy transition will affect electricity prices in Serbia?
}

\author{
Article history: \\ Received: 23 January 2020 \\ Sent for revision: 27 January 2020 \\ Received in revised form: 10 March 2020 \\ Accepted: 11 March 2020 \\ Available online: 31 March 2020
}

\begin{abstract}
The aim of this paper is to provide an answer on question if energy transition would have an effect on electricity prices in Serbia. As a part of the Energy Community, Serbia is oblidged to harmonize its energy regulation with the Europan Union. Even though electricity price in Serbia is at the lowest level in Europe, it has a high share in the household consumer basket. However, electricity price does not include the cost of $\mathrm{CO} 2$ emissions. The recent adoption of National Emission Reduction Plan implies Serbia's obligation to reduce emissions from large combustion plants by 2028. This commitment will entail significant investments and will influence the further development of the electricity sector. Accession of the Republic of Serbia to the EU and consequent implementation of EU ETS in the period 2023-2028, will have a significant impact on the EPS electricity cost production. At the moment, rough estimates show that this amount goes up to 2.5 eurocents per kWh produced by thermal power plants.
\end{abstract}

Keywords: electricity price, costs, CO2 emission, power plants.

\section{Kako će se energetska tranzicija uticati na cene električne energije u Srbiji?}

Apstrakt: Cilj ovog rada je da pruži odgovor na pitanje da li će proces tzv. energetske tranzicije uticati na cene električne energije u Srbiji. Kao deo Energetske zajednice, Srbija je obavezna da uskladi svoju energetsku

\footnotetext{
${ }^{1}$ Economics Institute, ivan.nikolic@ecinst.org.rs

${ }^{2}$ Economics Institute and University Singidunum.
} 
regulativu sa Evroskom unijom. lako je cena električne energije u Srbiji najniža u Evropi, ona ima veliko učešće u potrošačkoj korpi domaćinstava. Međutim, cena električne energije ne uključuje troškove emisije CO2. Nedavno usvajanje Nacionalnog plana za smanjenje emisije podrazumeva obavezu Srbije da redukuje emisije iz velikih postrojenja za sagorevanje do 2028. godine. Ta obaveza će podrazumevati značajna ulaganja i uticaće na dalji razvoj elektroenergetskog sektora. Imajući u vidu pristupanje Republike Srbije EU i samim tim pristup EU ETS mehanizmu u periodu 2023-2028., očekuje se da će to značajno uticati na troškove proizvodnje EPS-a. Trenutno, grube procene pokazuju da taj trošak može iznositi i do 2,5 eurocenti po kWh proizvedenom u termoelektranama.

Ključne reči: cena električne energije, troškovi, CO2 emisija, termoelektrane.

\section{Introduction}

Over the last few months, the broader public in Serbia was informed through different media sources that air in Serbia is extremely polluted. Monitoring of pollution emissions is very complex issue hindered by the variety of emission sources (transport, industry, resisidental sector, agricultural sector, etc.) as well as versatility of existing polluting substances (Cucurachi et al., 2014). Even though, there are many sources of air pollution, it is considered that coal-fired power plants are the main source of carbon dioxide and other pollutant emissions which have the highest share in greenhouse gasses.

During the last three decades, coal-fired power plants in the European Union (EU) have been facing with growing regulatory pressures to reduce air pollution. In order to reduce emission from large combustion plants, the European Union adopted the Directive 2001/80/EC on the limitation of emissions of certain pollutants into the air from large combustion plants (the LCP Directive) which entered into force in November 2001. The LCP Directive applies to installations whose rated installed capacity is greater than or equal to $50 \mathrm{MW}$, regardless of the type of fuel they use. In other words, large combustion plants include not only coal power plants, but also industrial plants, steel plants, oil refineries, etc.

The European Commission states that, for existing large combustion plants, there are two possible reduction mechanisms which are in line with this Directive. The first approach considers complying with the emission limit values at individual power plant, while the second approach considers that country should adopt the National Emission Reduction Plan (NERP) which defines maximum amount of the total emissions at thenational level for a certain year. 
LCD prescribed that NERP should be implemented for the period January 2018 - 2028.

Even though LCP Directive applies to emissions of acidifying pollutants, particles and ozone precursors, the carbon dixide is the most responsible for global waming problem (Florides and Christodoulides, 2009). In accordance to the polluter pays principle, the operational costs of coal-fired power plants have to cover the costs of emission of carbon dioxide. Considering costs, there are two mechanisms for reduction of carbon dixide emissions: a carbon tax as fiscal measure and an emission trading scheme (ETS) as a market-based mechanism (Hoffmann et al., 2008). The EU adopted ETS in 2005 and since then, this system has been recognized as a cornerstone for decarbonisation of the EU economy and the leading instrument of EU climate policy (Berghmans et al., 2014). Even though ETS is sophisticated policy instrument, it has been reformed as a consequence of many unanticiapeted factors and as a result of a learning-by-doing process (Teixsido, 2019). Using data for seven EU countries, Schmidt et al. (2012) found that the role of ETS scheme is limited and that the effects of its implementation can have controversial effects. There are a number of empirical studies, which focused on effects of ETS and robust empiricall evidence (Verde, 2018; Venmans, 2016; Wagner et al., 2014).

As a leader in fight agains climate change, the EU adopted regulation in order to achieve carbon neutrality by 2050 (European Commission, 2018). Pursuant to the EU accession context, Serbia, as a contracting party of the Energy Community treaty, should apply the EU environmental regulation in the electricity sector together with emission standards for power plants and carbon pricing (Energy Community, 2019a). Even though Energy Community contracting countries have been experiencing a period of complex energy transition, including and decarbonisation agendas, the seven out of nine countries (Albania, Bosnia and Herzegovina, Kosovo UNSCR 1244, North Macedonia, Georgia, Moldova, Montenegro, Serbia and Ukraine) have not introduced any kind of carbon pricing mechanism yet. The only exemptions are Ukraine, which recently introduced a nominal tax, and Montenegro, which introduced an excise tax on coal used for electricity generation.

The aim of this paper is to give an answer on question if energy transition would have an effect on electricity prices in Serbia. In that respect, the paper is structured in a following way. The first chapter introduces the current situation regarding emission from large combustion plants in Serbia. The second chapter is focused on the tariff system, while in the third section, electricity prices are compared with EU member countries. In the fourth section, discussion of the obtained results is presented, and, at the end, concluding remarks are given. 


\section{Emission from large combustion plants in Republic of Serbia}

Electricity generation from coal constitutes $54 \%$ of total installed power plants capacities. "Termoelektrane Nikola Tesla" (14 blocks) and "Termoelektrane Kostolac" (3 blocks) are run by the state-owned "Elektroprivreda Srbije" (EPS). Coal for the TPPs is supplied from EPS's own strip mines located in the vicinity of the thermal power plants. In addition to its own coal, EPS procures coal from underground coal mines from the state-owned company PEU "Resavica".

Figure 1. Emissions of combustion plants

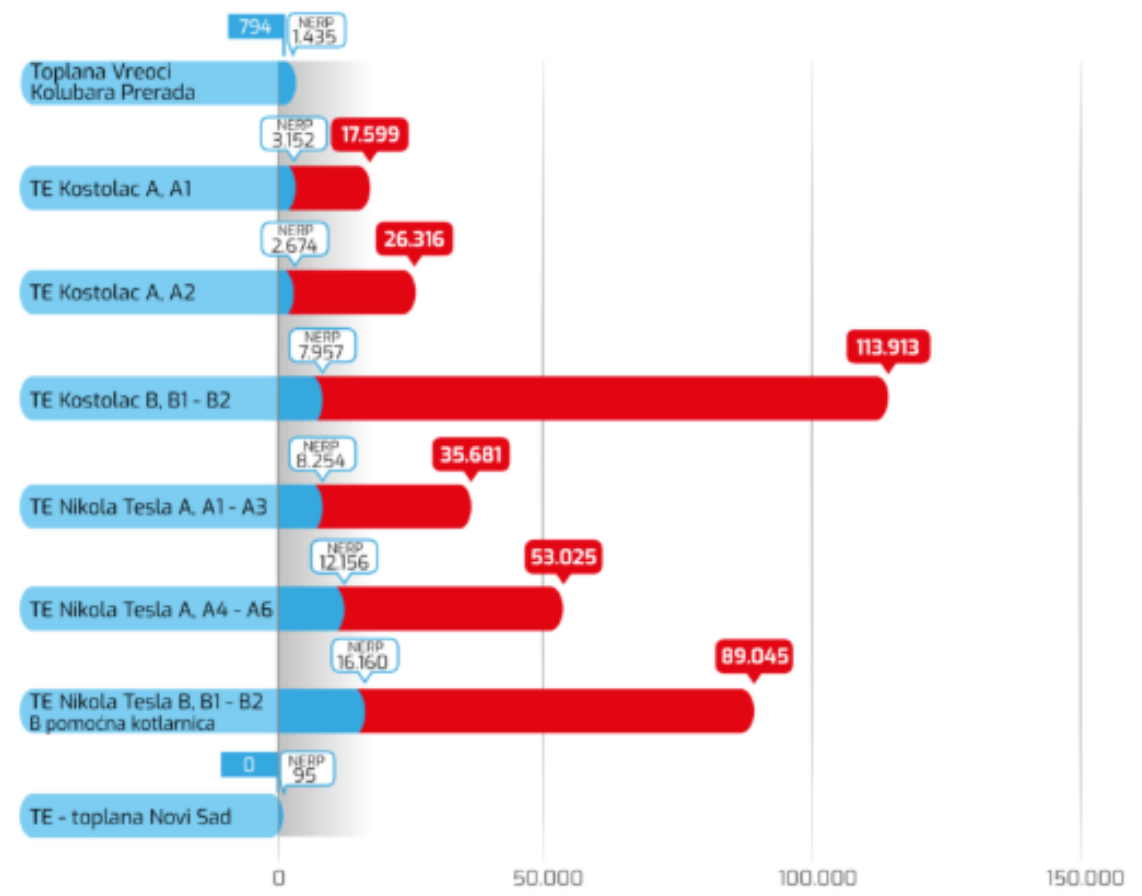

Source: https://www.reri.org.rs/en/energy-community-initiated-the-procedure-againstserbia-for-non-implementing-the-national-emission-reduction-plan/ 
All 17 power plants are under the LCP Directive -13 of them are under the NERP, while 4 are opted out plants. Twelve combustion plants which are subject to NERP published Report on the state of the environment for 2018. Acording to RERI (2020), these 12 large combustion plants emitted six times higher emission than it is allowed by NERP emission cellings for 2018 (Figure 1).

Considering current state of national power plants and their emission, extensive investments are needed for revitalization and modernization of the thermal power plant facilities. In accordance with the EPS Action Plan for the Protection of Environment for the period 2016-2025, around EUR 864 million will be invested in the thermal power plants and mine environmental rehabilitation projects. However, considering current electricity price in Serbia, as well as EPS's financial position, this ambitious investment plans are questionable.

Republic of Serbia, as a contracting party of the Energy Community Treaty, is oblidged to harmonize its regulation with the EU energy regulatory framework. Signing the Treaty in 2005, Republic of Serbia made a commitment to align its national level of emissions with the LCP Directive by December 31, 2017. In October 2013, based on Decision of the Ministerial Council of the Energy Community, Energy Community members reaffirmed their commitment in a way that they can adopt and implement NERP. Therefore, NERP can be applicable up to January 2028.

Serbian Government drafted NERP in December 2017, but it was not adopted until the end of January 2020. The goal of NERP is to reduce the total annual emissions of sulfur dioxide (SO2), nitrous oxide (NOx) and powdered matter from old large combustion plants in accordance with limiting values by 1 January 2028 at the latest. Responsible institutions for monitoring and evaluation of the NERP are the Ministry of Energy and Mining together with the Ministry of Environmental Protection. Ministry of Environmental Protection ensures the establishment of an inventory of annual emissions for the combustion plants covered by the NERP. The data from this inventory are submitted in the form of a report to the Energy Community Secretariat once a year for the previous year.

Besides this, in September 2019, the Energy Community Secretariat published an analysis of direct and hidden subsidies to the coal sector in Bosnia and Herzegovina, Kosovo*, Montenegro, North Macedonia, Serbia and Ukraine (Energy Community, 2019b). Considering the period 2015-2017, the Energy Community emphasized that electricity generation from coal was subsidized by direct budget transfers, international financial organization grants, 
reprogramming and failure to collect tax and social security contribution arrears from coal mines, debt write-offs, state loans, loans by state controlled institutions, state loan guarantees and SOE investment. The Energy Community highlighted that direct grants from the State's budget to underground coal mines of JP PEU Resavica and to TPP Nikola Tesla (TENT) of JP EPS Belgrade (for filters) potentially constitute State aid and should be scrutinized by the national Commission for State Aid Control. Also the DG Competition of the European Commission was informed as well.

\section{Electricity tariff system in Republic of Serbia}

There are two types of end customers in Serbia: (1) households and small customers who are entitled to a guaranteed supply at a regulated price and (2) non-households customers who are supplied on market terms.

Households and small customers have the right to supply at regulated prices. Small customers are legal entities and entrepreneurs with less than 50 employees and a total annual revenue up to EUR 10 million. In addition, the criterion for legal entities is that all facilities are connected to the distribution system of voltage lower than $1 \mathrm{kV}$ and that consumption in the previous calendar year was up to $30,000 \mathrm{kWh}$. Commercial, market supply conditions, are applied to industry, the service sector and all other non-households end customers.

Total electricity sales to end customers (both customer types) are around 28 billion $\mathrm{kWh}$, of which about $50 \%$ is regulated price sales. Overall sales are growing at an average rate of less than $1 \%$ per year, with household consumption slightly declining and rising at higher voltage levels, above all, in industry. Sales at regulated prices are declining, while the share of electricity sold at market with freely formed prices in increasing.

End customers cost component include:

- procurement costs, ie. electricity production,

- transmission tariffs and acces to distribution system,

- incentive compensation for eligible electricity producers,

- excise duty, and

- VAT.

The decision on regulated electricity prices for households and small customers is made by a guaranteed supplier (EPS) with the consent of the Energy Agency 52

Industrija, Vol.48, No.1, 2020 
of RS. Prices for the use of distribution and transmission networks are regulated for all customers. The decision on these prices is made by the operators of distribution (EPS Distribution, EPS subsidiary) and transmission system (Electric Power Network of Serbia, separate joint stock company) with the approval of the Energy Agency. Network costs are, in line with real costs, higher for customers connected to low voltage and much lower at medium and high voltage.

Prices for guaranteed electricity supply changed at the beginning of December 2019. They are higher than the price level set in October 2017 by about $3.9 \%$. Almost at the same time, the prices for access and use of the electricity transmission system were increased, as well as prices for access to the electricity distribution system. If there is an alternative bargain, households and small customers have the opportunity to change supplier. The change is free of charge and lasts for a maximum of 21 days, following the procedure established by the Rules on Supplier Change, adopted by the Energy Agency. Regulated prices for a guaranteed supply will be used, until the Energy Agency (in accordance with the criteria of the Energy Law) determines that there is no need for regulated prices.

For other consumers (industry, service sectors and all other customers who are not entitled to a guaranteed supply), the supply applies on a commercial or market basis. EPS sets prices for commercial supply in line with market conditions, taking into account possible competitive offers. The relevant wholesale market price for long-term transactions in our region is most often considered to be a forward price for the annual period, which is formed on the Hungarian HUPX Stock Exchange, in its HUDEX segment. Gradually, with its development, suppliers will also be able to rely on the Serbian SEEPEX stock exchange.

Prices for commercial supply, following HUDEX prices, have increased significantly and it is certain that, in this segment of consumption, EPS covers all justified costs and generates significant profits. On the other hand, EPS's exposure to the effects of stock price fluctuations is now low in accordance with the procurement of small value.

The mechanism by which end-user prices should follow market wholesale prices is not only desirable from the point of view of EU long-launched market reforms, but deviation from market conditions is considered to lead to a longterm unsustainable outcome. 
Since the first half of 2018, stock market prices have risen mainly under the influence of rising carbon dioxide emissions from thermal power plants under the EU Emissions Trading Scheme (ETS) from 10 to over EUR 25 per tonne. In the long run, these costs are expected to grow further. The trend in $\mathrm{CO} 2$ emissions since 2008 has fluctuated. The highest peak of almost EUR 30 per tonne was recorded in 2008. However, due to the financial crisis, as well as carbon credits outside the EU, the lowest point was EUR 3 per tonne in 2013 (Figure 2).

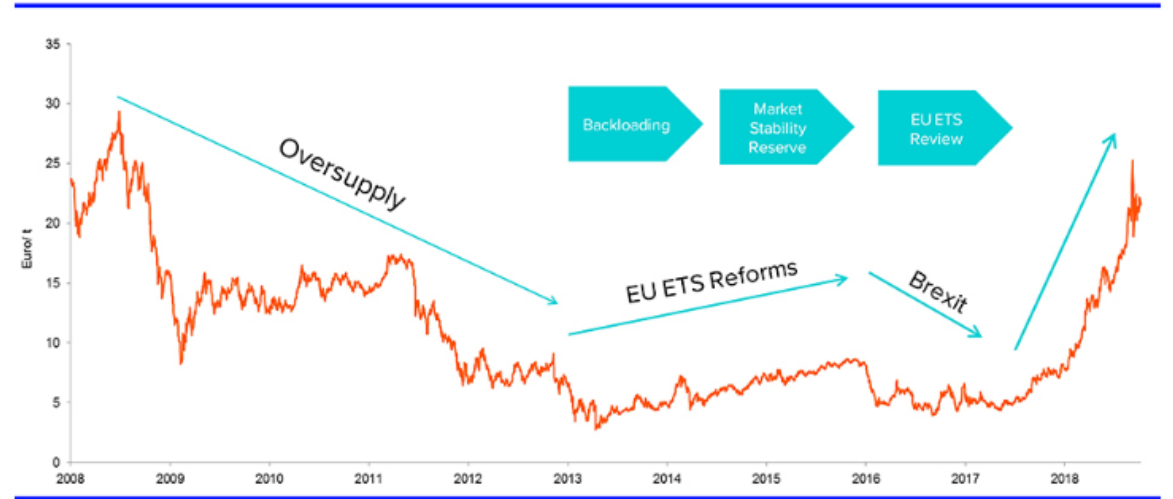

Source: https://www.refinitiv.com/perspectives/market-insights/will-high-europeancarbon-prices-last

The implementation of ETS in Serbia, which would become a reality upon joining the EU, would create a big problem for EPS and its market position. It is certain that environmental investments, especially desalination and associated operating costs, will realistically increase the total cost of EPS.

\section{Comparative analysis of electricity prices in Serbia and EU countries}

The price of electricity should enable the maintenance of the electricity system and new investments. More specifically, it is imperative to provide the required quantities of electricity, security of supply for the needs of the economy and households, respecting the principles of environmental protection, at 
economically sustainable prices, taking into account the problem of energy poverty. Therefore, social momentum is unavoidable and equally important.

Low electricity prices hamper the economically viable EPS operation and the future development of the sector. EPS employs over 29 thousand people, which is $2.9 \%$ of total number of employees in all companies in Serbia. EPS generates approximately $6 \%$ of gross value added of the total economy and pays $4.4 \%$ of all tax and fiscal outflows to the budget.

If one considers the final price (with taxes and fees included), the price of electricity for households in Serbia (first half of 2019) is at the level of 7 eurocent $/ \mathrm{kWh}$, while the price for industry is 10 eurocent $/ \mathrm{kWh}$ (Figure 3 ).

Figure 3. Electricity prices for households and industry customers - First half of 2019, eurocent/kWh

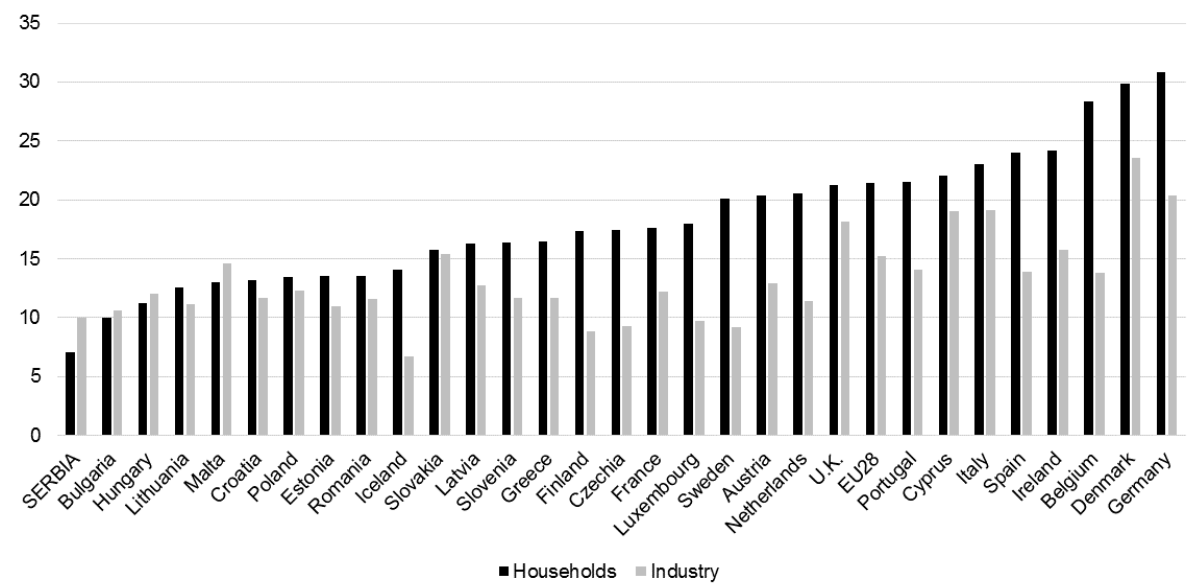

Source: Eurostat database

Although electricity prices for households and industrial consumers have been converging rapidly to the European average in recent years, in line with 2016, industrial electricity prices has a recurring increase of $46.1 \%$. Compared to the EU-28 price level in 2018, the average price of electricity in Serbia for households in the first half of 2019 was lower by about $67 \%$, while the average price for the non-households was lower by $33 \%$.

The price of electricity for the non households is already at an economically sustainable level and this is a consequence of its free market formation. Thus,

Industrija, Vol.48, No.1, 2020 
besides Bulgaria, Hungary and Malta, Serbia is one of the countries in which electricity is more expensive for industry than households.

The price of electricity is a very important determinant of population standards. This is best seen in Figure 4, which gives a weight to electricity in the formation of total inflation, as an approximate indicator of its importance in total household consumption. In Serbia, electricity costs still account closely $5 \%$ of total household expenses, which is a European record (with Sweden). Electricity is expensive for citizens despite its low cost, from EPS and economic analysts.

Figure 4. Electricity weightage in harmonised index of consumer prices in 2019

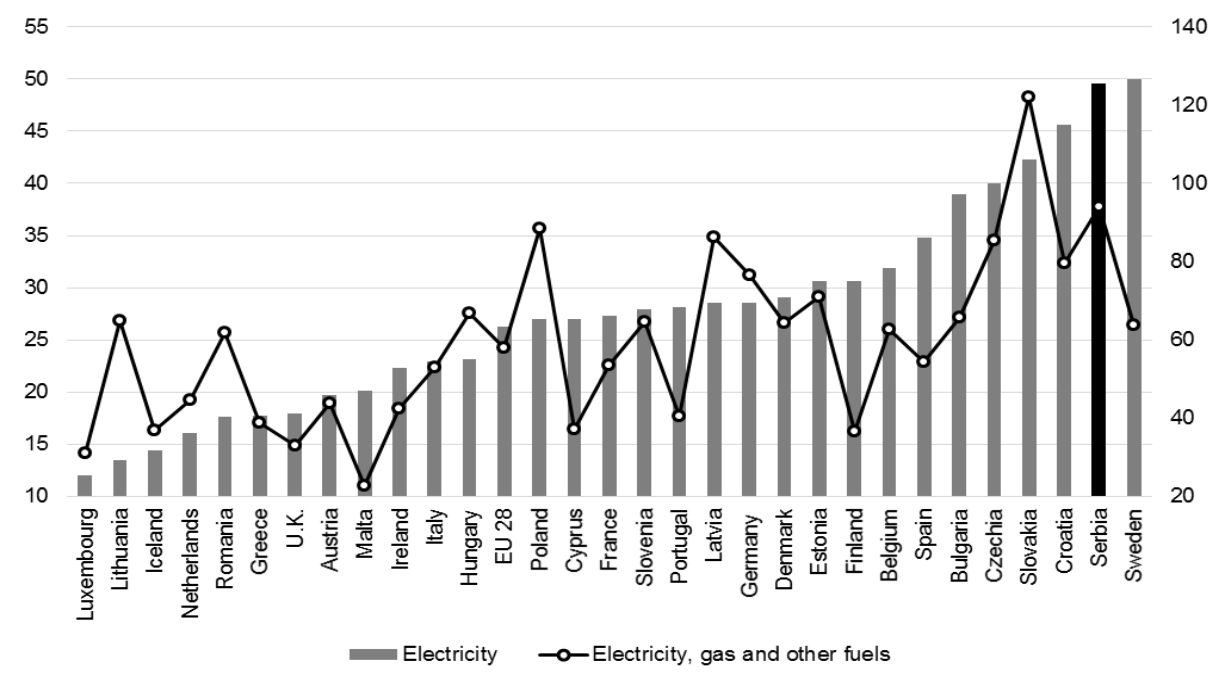

Source: Eurostat

On the other hand, despite the fact that the price of electricity has a high share in the household consumer basket, it does not include the cost of $\mathrm{CO} 2$ emissions. The recent adoption of NERP implies Serbia's obligation to reduce emissions from large combustion plants by 2028. This commitment will entail significant investments and will influence the further development of the electricity sector (competitiveness of domestic coal, choice of fuels and technology with lower $\mathrm{CO} 2$ emissions, rising production costs and the price of electricity itself). 


\section{Discussion}

Given the accession of the Republic of Serbia to the EU and the consequent accession to the EU ETS in the period 2023-2028, it is expected that CO2 certification prices will have a significant impact on the cost of EPS capacity on coal, i.e. on the price of electricity from their power plants. At the moment, rough estimations show that this amount goes up to 2.5 eurocents per kWh produced by thermal power plants.

Overall, the price of electricity in Europe depends on a number of factors including geopolitical situation, national energy mix, diversification of imports, grid costs, environmental costs, climate conditions and fiscal interventions (VAT, excise duty, tax etc). In European countries, since the last crisis until 2016, electricity consumption has stagnated, even the long-term trend has been slightly declining. The emergence is partly driven by increased energy efficiency on the consumption side, but also by the stagnation of industrial production caused by the crisis and its slow recovery. Despite a slow recovery, the current market outlook and global challenges affecting Europe will likely bring back consumption to this post-crisis period. The share of renewable energy sources grew until 2016, while stagnant electricity consumption was a key cause of stable prices (even reduced profitability of electricity companies).

Previously described market trends result in the postponement of projects using conventional fuels because, under current market conditions, construction is not economically viable due to the inability to generate returns on invested assets. The only conventional power plants that can currently withstand pressure on the market are depreciated coal power plants. At the same time, due to incentives for renewable energy in the European markets, there is a steady rise in prices for end customers.

As for the SEE region, the electricity balance is unlikely to change by the middle of the next decade. Moderate surpluses and export potential remain within $5 \%$ of total electricity produced. The main balance trends in the region are dictated by Romania, Bulgaria and Hungary - Bulgaria and Romania, as more serious exporters and Hungary as the largest importer. Croatia, Albania and Northern Macedonia are also importers. Montenegro varies from hydro-meteorological conditions due to its hydro-dominated production mix.

At present, only Hungary's decision to build the Paks 5 and 6 nuclear units (2.4 GW) can have a significant impact on the regional market in terms of importexport potential and change in energy transit routes, though this is less and less likely since its realization is late in many aspects. 
The main obstacle to the large energy transit from the western to the regional market is the interconnected capacities of Austria-Slovenia and AustriaHungary, both due to limited technical capacities and high costs of its use. Constant congestion is present, while the transmitted energy is predominantly destined for Italy, the market with the highest price.

\section{Conclusion}

The aim of this paper is to answer whether an energy transition with existing electricity prices is possible for Serbia. Based on the analysis of the tariff system, it can be concluded that the share of regulated prices for end customers is still high. Although the price of electricity has the highest share in the consumption basket of households in Serbia, it is three times lower than that of the EU-28 countries.

Regulated prices for a guaranteed supply need to undergo some adjustments to meet EU requirements and a commitment to energy transition towards low carbon technologies, which imposes new costs. Without going into more detailed analysis, it cannot be estimated what is the needed increase in regulated prices to cover justified costs and to ensure the long-term sustainable development of the system. Given the age of existing capacities, as well as the imperatives of energy transition, significant investments are needed. Without an adequate price level, EPS cannot be a credible investor for banks, which means that the practice of government guarantees on its borrowings may take time.

The question is also whether the target price for a guaranteed supply should be based on the aforementioned stock market e.g. HUDEX prices, since they also include the impact of the carbon footprint that EPS currently lacks.

An indispensable prerequisite for major changes in electricity prices for households is the increase in the number of energy-vulnerable customers who have earned the right to reduce their bills. Now the number of protected customers (just over 70 thousand) is many times lower than the number of customers that, according to the records of competent institutions, should be protected. Getting that protection is not easy. This is shown by practice in other countries. The government should intensify efforts to increase the number of energy-vulnerable customers faster. Funds can also be secured from the increased EPS profits generated by rising electricity prices. Finally, all these price issues and other related, complex issues like this cannot be addressed without a long-term strategic plan that EPS still lacks. 


\section{References}

Berghmans, N., Chèze, E., Alberola, B., Chevallier, J. (2014) The CO2 emissions of the European power sector: economic drivers and the climate-energy policies' contribution. CDC Climat Research, Working Paper No. 2014-17, CDC Climat Research.

Cucurachi, S., Sala, S., Laurent, A., Heijungs, R. (2014) Building and characterizing regional and global emission inventories of toxic pollutants. Environ. Sci. Technol., $48,5674-5682$.

Eurostat database available at: https://ec.europa.eu/eurostat/data/database

Energy Community Secretariat (2019a) Analyses on system adequacy and capacity mechanisms in the Western Balkans.

Energy Community Secretariat (2019b) Rocking the boat: what is keeping the energy community's coal sector afloat? Analysis of direct and selected hidden subsidies to coal electricity production in the Energy Community Contracting Parties.

EPS Action Plan for the Protection of Environment for the period 2016-2025. Available at: http://www.eps.rs/lat/Stranice/Sredina.aspx

European Commission (2001) Directive 2001/80/EC on the limitation of emissions of certain pollutants into the air from large combustion plants.

European Commission (2018) A clean planet for all - A European strategic long-term vision for a prosperous, modern, competitive and climate neutral economy, COM/2018/773 final. European Commission, Brussels 2018.

Florides, G. A., Christodoulides, P. (2009) Global warming and carbon dioxide through sciences. Environment International 35 (2009) 390-401.

Hoffmann, V., Trautmann, T., Schneider, M. (2008) A taxonomy for regulatory uncertainty - application to the European Emission Trading Scheme. Environmental science and policy 11, 712-722.

RERI (2020) available at https://www.reri.org.rs/en/not-great-not-terrible-review-of-thesecretariat-of-the-energy-community-annual-implementation-report-with-particular-

focus-on-national-emission-reduction-plan/

Schmidt, T. S., Schneider M., Rogge, K. S., Schuetz, M. J. A., Hoffmann, V. H. (2012) The effects of climate policy on the rate and direction of innovation: A survey of the EU ETS and the electricity sector. Environmental Innovation and Societal Transitions, Volume 2, March 2012, 23-48.

Teixsido, J., Verde, S. F., Nicolli, F. (2019) The impact of the EU Emissions Trading System on low-carbon technological change: The empirical evidence. Ecological Economics, Volume 164, October 2019, 106347.

Venmans, F.M.J. (2016) The effect of allocation above emissions and price uncertainty on abatement investments under the EU ETS, Journal of Cleaner Production, 126 (2016), 595-606.

Verde, Stefano F. (2018) The Impact of the EU Emissions Trading System on Competitiveness and Carbon Leakage (November 2018). Robert Schuman Centre for Advanced Studies Research Paper No. RSCAS 2018/53. Available at 
SSRN: https://ssrn.com/abstract=3293767 or http://dx.doi.org/10.2139/ssrn.3293 767.

Wagner, U., Muûls, M., Martin, R., Colmer, J. (2014) The Causal Effects of the European Union Emissions Trading Scheme: Evidence From French Manufacturing Plants, Mimeo. 